ISSN print: 2645 - 2944

Vol. 4 No. 2, June, 2020, pp $409-413$

DOI: https://doi.org/10.33003/fjs-2020-0402-225

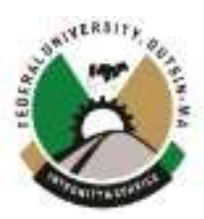

\title{
EXTRACTION AND PHYSICO-CHEMICAL PARAMETER ANALYSIS OF DESERT DATE (Balanite aegyptiaca) OIL FROM DUTSIN-MA
}

\author{
*Kamaluddeen Suleiman Kabo, Tijjani Ali and Abiodun B. Ogbesejana
}

Department of Applied Chemistry, Federal University Dutsin-Ma, Katsina State, Nigeria

*Corresponding author’s email: kskabo@fudutsinma.edu.ng

\begin{abstract}
Desert date (Balanites aegyptiaca) is perennial plant with a variety of application in vegetable oil, food preparation, condiment and medicine. This work covers extraction and physico-chemical parameters analysis: acid value, iodine value and saponification value of Balanite aegyptiaca seed oil samples obtainable at DutsinMa Area, Katsina State. Soxhlet extraction method was used in order to extract oil from the samples followed by its analysis according to standard protocols. The result shows that the seeds have high oil content, percent yield of $39.58 \%$ with the density of $0.91 \mathrm{~g} / \mathrm{cm}^{3}$, acid value 2.66 , iodine value $98.74 \mathrm{~g} / 100 \mathrm{~g}$, saponification value of $186.5 \mathrm{mgKOH} / \mathrm{g}$ and low moisture content of $2.6 \%$ was obtained. This shows that the seeds of Balanite aegyptiaca oil of Dutsin-Ma local area have high oil yield and good qualities making it suitable for use in a variety of applications to improve its value chain.
\end{abstract}

Keywords: Balanite aegyptiaca, oil extraction, Physico-chemical analysis, percent yield, Dutsin-Ma

\section{INTRODUCTION}

Edible oils are major dietary component and plays important nutritional role as concentrated source of energy and carrier of fat -soluble vitamins. They also impart flavour and taste to foods, provide essential fatty acids and fats are required for normal functions of the body (Frezzotte et al., 1956). The term oil is used in generic sense to describe all substances that are greasy or oily fluids at room temperature. They are non-volatile and are insoluble in water but are soluble in organic solvents. Oils from seeds or kernels or nuts along with proteins and carbohydrates, constitute the majority of foodstuffs. They are also found in wide industrial applications, like formulation of soap toiletries, paints, varnishes, bio-diesel and lubricant.

Balanites aegyptiaca (B. aegyptiaca) commonly called Desert date (also known as Aduwa in 'Hausa') is a semi-evergreen, usually spiny, extremely variable shrub or small tree of the Zygophyllaceae family that grows up to $12 \mathrm{~m}$ high. The bowl is usually straight with a 60 cmdiameter, often fluted, the branches are generally spread irregularly or pendulous, and sometimes form a round crown. The tree produces yellow date-like fruit. The trees bear heavy yields as many as 10,000 fruits annually on a mature tree in good condition each fruit, weighing $58 \mathrm{~g}$, consists of an epicarp (5-9\%), a mesocarp or pulp (28-33\%), an endocarp (49-54\%), and a kernel (8-12\%). The oil content of $B$. aegyptiaca seed approaches 50\% (Chapagain and Wiesman, 2005).

The plant grows in tropical and desert areas, it can be found in many kinds of habitats, tolerating a wide variety of soil types from sand to heavy clay and climatic moisture (Elfeel, 2010). $B$. aegyptiaca is perhaps one of the most wide-spread woody plants of the African continent. It is distributed through much of Africa from costal Mauritania and Senegal to Somalia and Egypt, southwards to Zambia and Zimbabwe, as well as in the Middle East from Yemen to Jordan and Israel (Sands, 2001). Benin, Burkina Faso, Cameroon, Chad, Djibouti, Ethiopia, Gambia, Ghana, Guinea, Bissau, Guinea, Ivory Coast, Kenya, Mali, Mauritania, Nigeria, Niger, Senegal, Sudan, Somalia, Tanzania, Togo, Uganda, Zaire, and Zambia are the primary African countries where Balanites are grown (Booth and Wickens, 1988). Algeria, Angola, Burundi, Central African Republic, Libya, Morocco, and Rwanda are the other African countries where Balanites are found (Hall and Walker, 1991). Both fruits and seed were widely used in many countries during the dry season and drought periods including Nigeria (Ladipo, 1989; Lockett et al., 2000), Ethiopia and Sudan (Grosskinsky and Gullick, 2001).

B. aegyptiaca is perennial plant used in food preparations, mainly in Africa and developing nations. It has variety of uses and most part of the plant is utilized including leaves thorns, back of root and fruit. The fruit is applied in the treatment liver ailments and as a purgative. It is edible fruit and its seeds have $40-87 \%$ edible oil; leaf and fruits are used in the rearing of animals like goats, sheep and camel, the oil is used for human consumption and cosmetics. The B. aegyptiaca seed oil is used in many places as ingredient and substituent to groundnut oil in the preparation of local food (Mohammed and Hamza 2008; Nardo et al., 2009). The seed oil of B.aegyptiacais reported to be rich in saturated fatty acids and is used as cooking oil (Hall and Walker, 1991; NRC, 2008). Reports on studies of B.aegyptiaca seed oil (Hussain et al., 1949; Cook et al., 1998; Mohamed et al., 2002) indicated that the seed oil consists of four major fatty acids: linolein, olein, stearic and palmitic acid but in varying proportions across study sites. This shows a variation of the oils' quantity with locations where the plant was found. In Nigeria, the seed oil obtained from B. aegyptiaca has been used especially in the Northwest part, as substitute to groundnut oil which is usually relatively expensive. This is in addition to medicinal uses such as treatment of skin diseases and rheumatism. B. aegyptiaca seed is considered as an extremely useful edible product. It contains good quality oil and high protein content (Mohamed et al., 2002; Abu-Al-Futuh, 1983). Despite such wide spread use, there is limited literature on the possible effects of long term consumption of the oil (AbdelRahim et al., 1986).

Also it is important to note that, differences in environment contribute to changes in both physical and chemical 
composition of plant extracts including oil. From available literature, there is limited attention and no work was carried out on extraction and physico-chemical parameters analysis was carried out to evaluate the B. aegyptiaca oil around this area despite the availability and abundance of this tree species in the northwest part, in particular Katsina State.

\section{MATERIALS AND METHODS}

The methods and procedures carried out in this research work are presented below

\section{Sample collection and preparation}

B. aegyptiaca fruits were bought from market in Dutsin-Ma, Katsina State. In order to remove the seeds, the fruits were crushed in steel pestle. The seeds were air dried and ground using mortar and pestle.

\section{Oil Extraction}

The extraction of oil was carried out by measuring $150 \mathrm{~mL} \mathrm{n}$ hexane into a round bottom flask. A sample weighing $100 \mathrm{~g}$ was placed in the thimble and then inserted in the centre of the extractor. The solvent was heated to maximum temperature of $68^{\circ} \mathrm{C}$ and when the solvent boiled, resulting in rising the vapour through the vertical tube into the condenser at the top. The liquid condensate dripped into the filter paper thimble in the centre which contained the solid sample to be extracted. The extract seeped through the pores of the thimble and filled the siphon tube, where it flowed back down into the round bottom flask. This was allowed to continue for about 4 hours so as to maximize the oil yield.

\section{FTIR Analysis}

The oil samples extracted were analyzed using Shimadzu FTIR$8400 \mathrm{~S}$ at the range of $4000-650 \mathrm{~cm}^{-1}$ and the resolution of $8 \mathrm{~cm}^{-}$ ${ }^{1}$ and spectra was generated. Characterization by FTIR was carried out for functional groups identification. The functional groups in B. aegyptiaca oil were analyzed to confirm the identity of the extracted oil.

Determination of Moisture Content of the Seed

Sample of the seeds are dried by weighing $30 \mathrm{~g}$ of a clean sample and introduced into the oven set at $80^{\circ} \mathrm{C}$ for $7 \mathrm{~h}$. sample weight was recorded after every $2 \mathrm{~h}$. until the reading become constant. The sample was then removed from the oven and placed in the desiccator for 30 minutes to cool then removed and re-weighed. The percentage moisture content in the seeds was calculated using the formula in equation (1) (Capreda, 2013).

$$
\text { Percent moisture }=\frac{w_{1}-w_{2}}{w_{1}} \times 100 \%
$$

\section{Determination of the Percentage yield}

After the oil is obtained from the extraction process, it was transferred into a measuring cylinder which was placed over a water bath for 30 minutes set at $70^{\circ} \mathrm{C}$ in order to ensure complete evaporation of the solvent. The volume of the oil was recorded and then its weight measured, percent yield is then calculated using equation (2) (Capreda, 2013).

$$
\text { PercentageYield }=\frac{w_{1}}{w_{2}} \times 100 \% \text {. }
$$

Where: $\mathrm{w}_{1}=$ weight of oil extracted; $\mathrm{w}_{2}=$ weight of sample used Determination of Specific Density

Density of oil is related to its fatty acid composition and minor components. An oil with low density value means it contains low molecular weight fatty acids; likewise, thus, it will have high saponification value, making it suitable for use in soap production (Capreda, 2013, John, 2008).

The specific density was determined by measuring $25 \mathrm{ml}$ an already measuring cylinder, followed by taking the weight of the cylinder and the oil. Actual the weight of the oil was obtained from difference in the weight of the cylinder with the weight of the oil and cylinder. The specific density of the oil is calculated using the formula in equation (3).

$$
\text { S.D. }=\frac{\left(w_{1}-w_{o}\right)}{v_{o}}
$$

Where $\mathrm{W}_{1}=$ weight of empty measuring cylinder + oil, $\mathrm{W}_{\mathrm{o}}=$ weight of measuring cylinder,

$\mathrm{V}_{\mathrm{o}}=$ volume of oil

\section{Determination of Acid Value}

The oil sample $(2.0 \mathrm{~g})$ was placed into a dried $250 \mathrm{~mL}$ conical flask. Then, $25 \mathrm{~mL}$ of absolute ethanol was added followed 3 drops of phenolphthalein indicator. Shaking water bath was then used in heating the mixture for 5 minutes. The mixture was it was titrated against $0.1 \mathrm{M} \mathrm{KOH}$ while it was still hot with vigorous shaking in order to achieve thorough mixing until pink color was observed. The volume of $0.1 \mathrm{M} \mathrm{KOH}$ consumed by an acid was recorded. The acid value was calculated as using equation (4) (Capreda, 2013).

$A . V .=\frac{56.1 \times v \times M}{m}$.

Where $\mathrm{V}=$ volume of $\mathrm{KOH}$ used; $\mathrm{M}=$ molarity of $\mathrm{KOH}$ and $\mathrm{m}$ $=$ mass of sample.

\section{Determination of Iodine Value}

The oil sample $(0.25 \mathrm{~g})$ was weighed into a $250 \mathrm{~mL}$ conical flask. Thereafter, $10 \mathrm{~mL}$ of chloroform and $30 \mathrm{~mL}$ of Hanus iodine solution were sequentially added. The solution was allowed to shake for 30 minutes in securely closed flask under darkness. After that, $10 \mathrm{~mL}$ of $15 \%$ potassium iodide solution was added, then shaken, followed by addition of $100 \mathrm{~mL}$ distilled water. The mixture was then titrated with the iodine solution against $0.1 \mathrm{M}$ Sodium thiosulfate $\left(\mathrm{Na}_{2} \mathrm{~S}_{2} \mathrm{O}_{3}\right)$ (Capreda, 2013). The iodine value was calculated using the formula in equation (5)

$I . V .=12.69 \times C \times \frac{\left(v_{1}-v_{2}\right)}{m} \ldots \ldots \ldots \ldots \ldots$ (5)

Where $\mathrm{C}=$ Concentration of $\mathrm{Na}_{2} \mathrm{~S}_{2} \mathrm{O}_{3}$ used; $\mathrm{V}_{1}=$ volume of $\mathrm{Na}_{2} \mathrm{~S}_{2} \mathrm{O}_{3}$ used for the blank; $\mathrm{V}_{2}=$

Volume of $\mathrm{Na}_{2} \mathrm{~S}_{2} \mathrm{O}_{3}$ used for sample; $\mathrm{m}=$ mass of the sample. 3.2.5 Saponification Number of Oil

Two grams of the oil sample was added to a flask containing 30 $\mathrm{mL}$ ethanolic $\mathrm{KOH}$ which was attached to a condenser for 30 minutes under reflux to enable the sample to dissolve fully. After sample was cooled, $1 \mathrm{~mL}$ of phenolphthalein was added 
and titrated with $0.5 \mathrm{M} \mathrm{HCl}$ until a pink endpoint has reached (Capreda, 2013, AOAC, 1998).

Saponification value was calculated from the formula in equation

$\mathrm{S} . \mathrm{V} .=\frac{(S-B) \times M \times 56.1}{\text { Sample weight }(g)}$

Where $\mathrm{S}=$ sample titre value

$\mathrm{B}=$ blank titre value

$\mathrm{M}=$ molarity of the $\mathrm{HCl}$

$56.1=$ molecular weight of $\mathrm{KOH}$

\section{RESULTS AND DISCUSSION}

FTIR Analysis

The band $3007 \mathrm{~cm}^{-1}$ corresponds to $\mathrm{C}-\mathrm{H}$ stretch typical of alkene. The peak at $2921 \mathrm{~cm}^{-1}$ corresponds to C-H stretch of alkane, whileabsorption at $1745 \mathrm{~cm}^{-1}$ observed is attributable to $\mathrm{C}=\mathrm{O}$ stretch for esters. This is supported by absorptions at 1210$1163 \mathrm{~cm}^{-1}$ corresponds to $\mathrm{O}-\mathrm{C}$ stretch for the same functionality (ester). Band at $724 \mathrm{~cm}^{-1}$ is assignable to $\mathrm{C}=\mathrm{C}$ bend of alkenes. From the FTIR results analyses, all the functional groups detected represent those commonly found in naturally occurring oils.

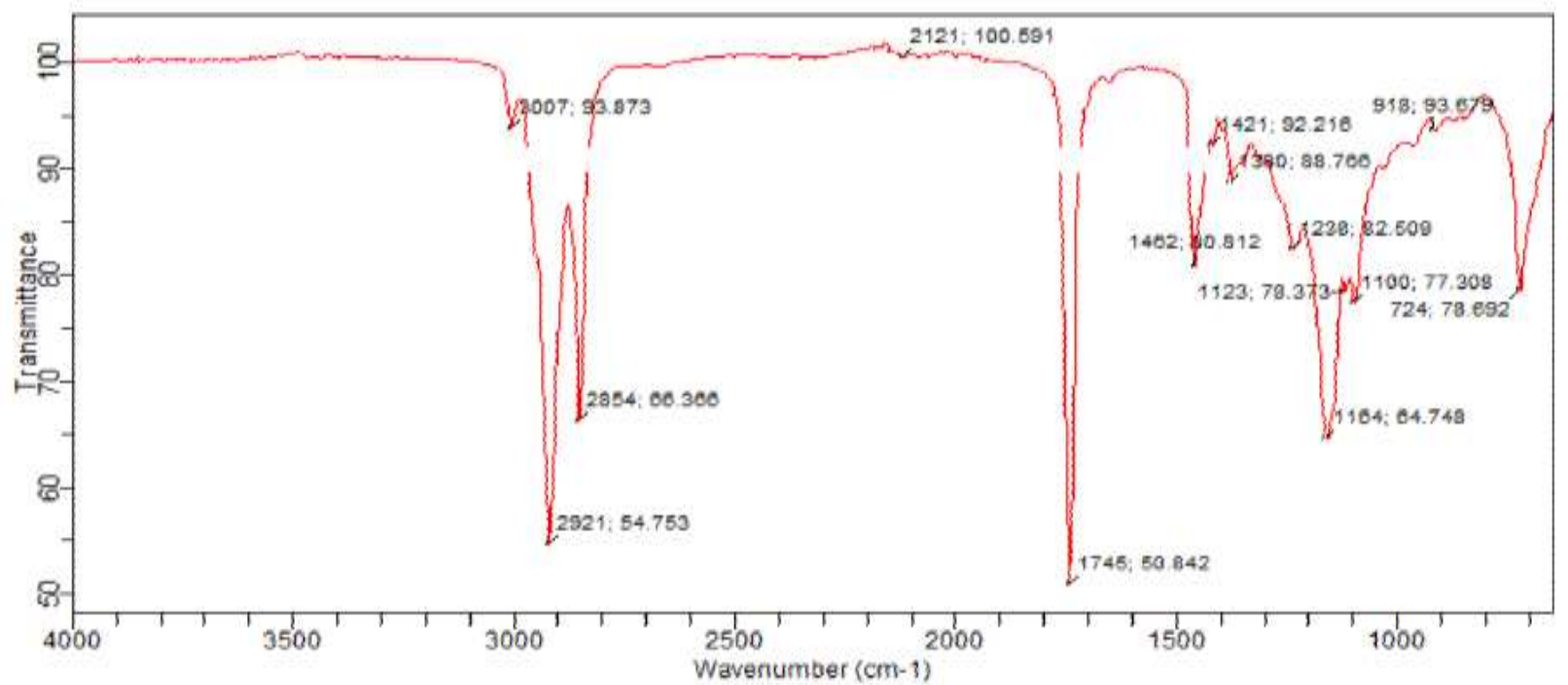

Fig 1 FTIR spectrum of B. aegyptiaca oil

\section{Physico-Chemical Parameter Analysis}

The result obtained from the analysis of physical parameters is presented in Table 1 . The result includes oil yield, moisture content of the sample, Color, odour, density and physical state.

Table 1: Results on Physical Parameter Analysis

\begin{tabular}{ll}
\hline Parameter & Result \\
\hline Yield $(\%)$ & 39.58 \\
Color & Pale yellow \\
Odour & Mild \\
Moisture Content $(\%)$ & 2.6 \\
Density $(\mathrm{g} / \mathrm{ml})$ & 0.94 \\
Physical State & Liquid \\
\hline
\end{tabular}

Oil content yield was determined to be $39.58 \%$ which is lower than that reported by (Elfeel, 2010) which was $50 \%$. However, the oil content of $39.58 \%$ is significant for a sample to be economically suitable for use as oil source.

Moisture content was found to be $2.6 \%$ which is similar with that reported by (Sara, 2005). The yellow colour in Balanites oil is similar to that reported by Babagana et.al. (2011) and Babeker (2013). The yellow colouration is due to presence of carotene which according to FAO/WHO (1994) and WHO (2004), makes Balanites oil nutritionally important as carotenoids are highly unsaturated polyisoprene hydrocarbons lipids which are precursors for vitamin A (WHO, 2004). The light yellow colour of the oil also makes it visually attractive thus, along with other good attributes makes Balanites oil a sustainable and economical market commodity. The density obtained $(0.94 \mathrm{~g} / \mathrm{ml})$ is relatively higher than $0.87 \mathrm{~g} / \mathrm{ml}$ reported by Babagana et al. (2011), and also lower than 1.001 $\mathrm{g} / \mathrm{ml}$ (Manji et al., 2013) but closed to the value $0.92 \mathrm{~g} / \mathrm{ml}$ (Babeker, 2013).

The result obtained from the analysis of chemical parameters is as presented in Table 2. The result includes saponification value, acid value and iodine value. 
Table 2: Result on Chemical Parameter Analysis

\begin{tabular}{ll}
\hline Parameter & Result \\
\hline Saponification $(\mathrm{mgKOH} / \mathrm{g})$ & 186.5 \\
Acid value $(\mathrm{mgKOH} / \mathrm{g})$ & 2.66 \\
Iodine Value $(\mathrm{mg} / 100 \mathrm{~g})$ & 98.74 \\
\hline
\end{tabular}

The acid value obtained from $B$. aegyptiaca seed oil was 2.66 $\mathrm{mg} \mathrm{KOH} / \mathrm{g}$. This is a bit lower than $22.3 \mathrm{mg} \mathrm{KOH} / \mathrm{g}$ reported by Fokou et al., (2009). However, the relative incrses in the amounts of free fatty acid can be attributed to the method adopted in the seed processing, duration of storage or drying of the seeds. Acid value can also be increased due to relative rise in temperature during extraction, processing or storage.

Saponification value obtained in this work is $186.5 \mathrm{mgKOH} / \mathrm{g}$. High saponification values indicate high proportion of lower fatty acid. This high value indicates that the oil could be used in the manufacture of soap (Kirschenbauer, 1995). However, the saponification value was much lower than $242 \mathrm{mg} \mathrm{KOH} / \mathrm{g}$ in $B$. aegyptiaca reported by Fokou, et al., (2009).

Iodine number is the number of milligrams of iodine absorbed by one-gram fat, the iodine number gives an indication of the number of double bonds in any particular oil or fat, thus $98.74 \mathrm{~g} / 100 \mathrm{~g}$ I.N indicates the high level of unsaturation. However, the iodine value 98.74 obtained is higher than the values obtained by Babagana et.al., (2011), and Manji et.al., (2013).

\section{CONCLUSION}

The results indicate that Balanites obtainable in Dutsin-Ma has an oil yield $39.58 \%$ with good physicochemical properties, the oil has low acid value making it to be stored for a long time, and it has high saponification value which makes it a good raw material for soap production. The overall physicochemical characteristics $B$. aegyptiaca oil makes it a potential raw material for cosmetics, soap and food processing (as edible vegetable oil) and for use as substrate in biofuels production.

\section{REFERENCES}

Abdel-Rahim, E.A., El-Saadany, S.S. and Wasif, M.M. (1986). Chemical and physical studies on Balanites aegyptiaca oil. Fasc 37: $81-85$.

Abu-Al-Futuh, (1983), M. Balanites aegyptiaca: an unutilized raw material potential ready for agro-industrial exploitation. United Nations Industrial Development Organization,Vienna, 100 .

AOAC. (1998). Official Methods of analysis of the Association of Official Analytical Chemists, 16th Edition, Gaithersburg, USA.

Aremu, M. O., Olonisakin, A., Bako, D. A. and Madu, P. C. (2006). Compositional studies and physicochemical characteristics of Cashew nut flour. Pak. J. Nutr. 5, 328-333

Babagana Gutti, Shittu S. Bamidele and Idris M. Bugaje (2011) characterization and Composition of Balanites aegyptiacaseed oil and its potential as biodiesel feed stock in Nigeria. Journal of
Applied Phytotechnology in environmental sanitation1 (1): 2935.

Babeker,M.A. (2013). Physicochemical Properties of Laloub Seed Oil. M.Sc. Thesis. 29-45. Faculty of Agriculture, University of Khartoum.

Booth, F.E.M., Wickens, G.E. (1988). Non-timber uses of selected Arid zone trees and shrubs in Africa FAO Conservation Guide 19:18-2.

Capreda, S. (2013): Introduction to Biomass Energy Conversions CRC Press. p 119 - 201. Tailor and Francis Group. Florida, USA.

Chapagain, B. P., Wiesman, Z. (2005). Variation in diosgenin level in seed kernels among different provenances of Balanites aegyptiaca, Del. (Zygophyll aceae) and its correlation with oil content. Afric. J. Biotechnol. Sparg, S.G vol.(4),1209-1213.

Cook, A.J., Vanderjagt, D.J., Pastuszyn, A., Mounkaila, G., Glew, R.S. and Glew, R.H. (1998). Nutrient content of two indigenous plant foods of Western Sahel: Balanites aegyptiaca and maerua crassifolia. Journal of Food Composition and Analysis vol. 11: 221-230.

Elfeel A.A (2010) Variability in Balanites aegyptiaca seed Kernel oil, protein and minerals contents between and within locations Agriculture and Biology Journal of North America. 1(2): $170-174$

FAO/WHO, (1994). Fats and oils in human nutrition: FAO Food and WHO, Vitamin and mineral requirements in human nutrition. Appendix 1: Recommended nutrient intakes.

Fokou, E., Achu, M. B. and Tchouanguep, M. F. (2004). Preliminary nutritional evaluation of five species of egusi seeds in Cameroun. Afr. J. Food Agric. Nur. Dev. 4, 1-11

Frezzotte, G.; M. Manni and A. Aten. (1956). Olive oil processing in rural mills. Rome

Grosskinsky B and Gullick C., (2001). Potential of indigenous food plants to support and strengthen livelihoods in Southern Sudan. In Kenyatta C and Henderson A. (2001). The potential of indigenous wild foods. Workshop proceedings. USAID/OFDA, Mombassa, Kenya.

Hall, J.B. and Walker, H.D. (1991). Balanites aegyptiaca: A monograph. School of agriculture and forest sciences Publication Number 3. University of Wales, Bangor. 
Hussain, S.A., Dollear, F.G. and O'Connor, R.T. (1949). Oil from the kernels of fruit, Balanites aegyptiaca. Journal of the American Oil Chemists' Society 26 (12) 730732.

John K. (2008), Analytical chemistry for technicians. 3rd Edn., Kalyan Publishers, New Delhi, India Pp 432-433.

Kirschenbauer, H. G. (1995). Fats and Oils: An outline of their chemistry and Technology. Reinhold Publishing and Co., New York

Ladipo, D.O. (1989). Balanites aegyptiaca: Native tree with potential for agroforestry and arid zone afforestation in Nigeria. IFS- ICRAF-IUFRO seminar "Trees and Development" Nairobi February

Locket C.T, Calvert C.C and Grivetti L.E., (2000). Energy and micronutrient composition of dietary and medicinal wild plants consumed during drought. Study of rural Fulani, northeastern Nigeria. Int J Food Sci. 51(3):195-208.

Manji A. J., Sarah E. E. and Modibbo U. U (2013). Studies on the potentials of Balanites aegyptiacaseed oil as raw material for the production of liquid cleansing agents. Department of Industrial Chemistry, Modibbo Adama University of Technology, P. M. B. 2076, Yola, Adamawa State, Nigeria.

Mohammed, M.I., and Hamza, Z.U (2008) physicochemical properties of oil extracts from Sesamum Indicum L-Seeds grown in Jigawa State Nigeria. Jour. of App. Scien and Env. Mgt,; 12 : 99-104.
Mohamed, A.M., Wolf, W. and Speiss WEL. (2002). Physical, morphological and chemical characteristics, oil recovery and fatty acid composition of Balanites aegyptiaca Del. Kernels. Plant Foods Human Nutrition 57:179-189.

Nardo, S.M., Obida, W., and Tiyato, G.O., Worochekke, A.U. (2009). Toxicity of crude Balanites Aegyptiaca seed oil in Rates. Jour. of Amer. Sci. 5(6): 13-16.

NRC (2008), Lost Crops of Africa; Fruits, The National Academic Press. National Research. Council, Washington, D, C, USA, Vol (3) p $23-40$

WHO, (2004). Vitamin and mineral requirements in human nutrition. Appendix 1: Recommended nutrient intakes. WHO, Geneva, Switzerland 